\title{
Does One Size Really Fit All? Transitional Justice Processes and Commemoration in Post-conflict Santiago Atitlán, Guatemala
}

\author{
Michelle Dragoo \\ Department of Anthropology, California State University, USA
}

Copyright $(2016$ by authors, all rights reserved. Authors agree that this article remains permanently open access under the terms of the Creative Commons Attribution License 4.0 international License

\begin{abstract}
This paper describes "Parque de la Paz" located in Santiago Atitlán, Guatemala, a memorial space commemorating the community uprising that ousted military occupation from the city. The paper focuses on current community perceptions concerning the events' significance in history, and the parks use as a commemoration site. I will discuss the discrepancy in historical accounts, generational differences, and the marginalization of importance of the event within the community. An overview of transitional justice will be given in an effort to provide context. Current theories of transitional justice are reviewed as they apply to memorialization efforts in Atitlán Guatemala following the 30-year civil war that ended in 1997.
\end{abstract}

Keywords Memorialization, Transitional Justice, Santiago Atitlan, Guatemala

\section{Introduction}

"A Piece of Paradise", "A Land of Untouched Beauty", and "A Place Untouched by Time" are popular phrases regarding Guatemala that are all too common in various travel log's or tourist guides written by captivated visitors. Yet, this majestic place contains a multitude of secrets, hidden from view to most unsuspecting tourists. In particular, the small town of Santiago Atitlán, which rests on the shores of the lake called Lago de Atitlán, conceals its tumultuous past to the extent that all remnants are barely perceptible, even to the educated visitor in search of it. However, one lone monument stands to attest this little town's major triumph in the history of the Guatemalan civil war; The Parque de la Paz, or, the Peace Park.

The Peace Park stands to memorialize the momentous point in history when Santiagans, or Atitecos, banded together and ousted the military from their small town. This was the first time in Guatemalan's long, complicated history of conquest and control that the indigenous population ousted their occupiers. In the process, 13 Atitecos were killed. Despite the significance of this historic occasion, the event seems to be suppressed from collective memory. Why, then, would a town with seemingly so much to be proud of, want to ignore a crucial point of the history that is so significant to their collective identities? Some scholars have argued that this is due to a combination of the climate of fear, the absence of education about the event in government mandated curriculum, or, what some Atitecos suggest, an attitude of moving forward without dwelling on a painful past.

The purpose of this study is to investigate the role of memorialization within transitional justice mechanisms, in order to investigate the issue of 'forgetting' in the town of Santiago Atitlán in Guatemala.

\section{Materials and Methods}

Methodology consists of 1:1 interviews with community citizens and local leaders. Initial discussion and questions were broad in scope to gain trust and to determine level of confidence with the topic. As the conversation progressed, the questions became narrower with the ability to obtain information of a more sensitive in nature. To begin with, I wanted to initiate casual conversations with local citizens in order to ease into asking questions about Santiago's past. I knew genocide was a delicate topic in Guatemala (a sensitivity that intensified by the "culture of fear") and that not long ago, a survivor would be placing their lives in danger if they dared to utter their testimony. This fear was justified in that researchers, human rights activists, and workers from international NGO's, were looked at with suspicion when they came to recover survivor accounts, and were in danger for their investigations.

This approach was based on Frank M. Afflitto's [1] ethnographic methods of Participatory Action Research, or 
PAR. PAR requires the researcher to actively participate with the group(s) (s)he intends to study. This allows close proximity to the social structures that underlie social change. Instead of developing questions based on a pre-determined theoretical paradigm, the method allows interactions to help shape the project. This design also, allows participants to interact and ask questions of the researcher, and to indicate whether or not they have relevant information. The strength of participatory research is flexibility, and the ability of the researcher to discover or terminate 'erroneous' lines of inquiry and to disregard any prior explanations of certain phenomenon that might actually constrain observation and thought.

Using this methodology, my intention was to find groups, and/or attend events during my stay in Santiago and to engage people in an organic way. Ultimately, my hope was to employ casual conversational approaches in order to gauge a participant's level of comfort when speaking about Santiago's history. From there, I could begin to discern what types of questions I might ask. My questions were intended to learn about the history that propelled the creation of the commemoration site called the "Parque de la Paz", or the Peace Park. I also wanted to learn about how Atitecos felt about the absence of this history from the educational curriculum, designed by the national government, implemented in more recent educational reformations.

In addition to conversations and interviews, I also conducted observations in the Peace Park in two-hour segments, most days of the week. I would visit the park to observe what segments of the population visit the park, what they do there, and why.

\section{Theoretical Perspective: Transitional Justice}

Analysis of findings will be based on recommendations found within the Transitional Justice Toolbox.

More narrowly, I focus on memorialization in post conflict society; a strand within the anthropology of transitional justice that deals with truth, voice, and narrative. Commemoration and memorialization of the victims of mass violence is a key component of social reconstruction with a goal of maintaining peaceful reforms. Memorialization, on the local level, however, is not well studied in terms of its impact on transitional societies [2]. It is my intention, therefore, to try to contribute to this scholarship by concentrating on the "Parque de la Paz" in the community of Santiago Atitlán.

\subsection{Transitional Justice: A Historical Overview}

In recent years, the UN has become synonymous with peacekeeping, and has become the main entity for setting up peacekeeping operations, establishing peace, and monitoring human rights violations [3]. In the first forty years of the
UN's existence there were fifteen operations set up to restore or maintain peace [3]. Though there were a significant number of UN operations between the two World Wars, the UN began to actually formalize operations in 1956 with the establishment of the United Nations Emergency Force (UNEF) and with intervention in the relations between Egypt and Israel [3]. The UN peacekeeping mechanisms have become known as $\mathrm{TJ}$, and have become part of what is called the $\mathrm{TJ}$ toolkit.

$\mathrm{TJ}$ is a relatively new field of academic study that emerged in the 1980's to deal specifically with questions regarding how societies come to terms with the after effects of genocide or mass atrocity [4]. TJ has developed into a discipline, and has become an integral part of liberal peacebuilding operations [5]. TJ is implemented with a goal of developing sustainable peace in war-torn countries and aims towards a government that functions under some form of democracy [5].

\subsection{Mechanisms of Transitional Justice}

The goal of TJ is total absence of violence and of social injustice [5]. The United Nation's report titled "Notes from the Secretary-General: United Nations Approach", describes that the mechanisms of TJ fall into two umbrella groups; judicial and non-judicial processes [6]. In the same report, five components of transitional justice programs are outlined [6]. Judicial processes, sometimes referred to as punitive justice, entails prosecution for crime and, in some cases, may actually take the form of revenge. These components are prosecution initiatives (those that involve bringing those responsible for committing crimes against humanity to justice) and facilitating initiatives in respect of the right to truth (those mechanisms that involve investigating past human rights abuses). Non-judicial processes sometimes referred to as restorative justice, works towards a positive approach and looks to root cause for injustice. Components include: delivering reparations (mechanisms that provide material and symbolic benefits to victims), institutional reform (restoring public institutions from previous regime to those that sustain peace, protect human rights, and foster a culture of respect for the rule of law), and national consultations (a human rights-based approach that engages meaningful public participation) [6].

\subsubsection{Prosecution Initiatives: Criminal Trials}

Trials can take the form of criminal trials, war crimes tribunals, international law, the International Criminal Court (ICC), or trials by regional institutions. These trials can be accomplished at the local, regional or international level and the trial can be of a person, group for crimes of genocide, crimes against humanity, war crimes, or crimes of aggression [7]. While the most notable trials are at the international level (i.e. the Nuremberg Trials), most recent trials are implemented at the state level (i.e Rwanda and Guatemala) [4]. Trials are the instrument in both reparation and lustration as they seek to find truth. 


\subsubsection{Institutional Reform: Lustration}

Lustration is derived from the Latin for "purification". In $\mathrm{TJ}$, it is the means in which some countries deal with human rights abuses by purging the group and/or individuals in high positions that had supported the old regime ideology in perpetration of the human rights violations [4]. Lustration saw its beginnings in 1990's in Eastern Europe beginning in Bulgaria, and including Hungary, Albania, Poland and Serbia [9]. Lustration is most often carried out by members of the new administration as they rid the country of those perpetrators responsible for inflicting crimes against the state and crimes against humanity [9]. Lustration may also occur when, fearing capture or retribution, leaders of the old regime flee from the country to perceived safety [10].

\subsubsection{Truth Seeking Initiatives: Historical Preservation through Memorials}

Preservation of history, another TJ mechanism, can take the form of education that may be formal, informal, or may be carried out in the form of memorials (i.e. museums, or war memorials that commemorate the event). While on the surface this is seemingly an excellent means of upholding the $\mathrm{TJ}$ mechanisms for reconciliation, little attention has been given to the ramifications of the decision to memorialize with monuments. Most literature about memorialization is limited to types of memorials. There is little literature and research about the impact of these memorials on society and whether they have legitimate place in transitional justice.

Barsalu and Baster [8] have identified several types of memorials with common features, and important facets of memorialization that warrants research. Memorials to genocide or mass killings can sometimes be centered on human remains. It is felt that hundreds of bodies on display will help to emphasize the sheer scope of the atrocity with the goal of "never again" [8]. When ethnic conflict is memorialized, the authors found that the memorials are ethnocentric and favor one group over the other. The authors also bring light to the importance of timing of memorialization. The memorials that are erected soon after the event often lack insight and perspective and may serve to escalate the polarity between the affected groups. The authors found that the memorials that are established after the truth-telling and legal accountability processes have been completed are more holistic in nature and may reflect a broader perspective and understanding of the events. This type of monument and the passing of time are less polarizing. The authors also agree that any memorialization must be driven by insiders rather than outsiders, as any attempt to portray events from outsiders tend to be met with hostility at worst and indifference at best [8].

Memorialization can serve several purposes, it may serve to honor those who died during a conflict and it also may serve as a means of analyzing the past [8]. On one hand, memorialization can be a positive action by serving as a pathway to a new national identity. On the other hand, it can be negative action because it is the victor that determines how the event is remembered [11]. Many times the memorials interpret historic events in a manner that honors the ruling party and shames the loser [11]. Thus the "memories" are shaped by those in power and can serve as a means for long term hatred and grievance [8]. Despite the intent, the emotions around the memorials can be highly charged. Memorialization walks a tightrope between the political arena, the traumatic events commemorated and public discourse [12]. The most important factors surrounding memorialization are the concerns regarding personal and community identification with these memorials.

\section{Historical Background: Santiago Atitlán and the 36 Year Civil War}

After the United States supported overthrow of Juan José Arévalo and Jacobo Arbenz Guzmán in 1954, Guatemala was placed under the authority of a corrupt and cruel government [13]. In the 1960's, leftist groups emerged in response to the government and its treatment of the majority of the Guatemalan population [14]. Specifically, in 1960, one-third of the Guatemalan military rose in revolt against the government of General Miguel Ydigoras Fuentes [14]. This group formed the Fuerzas Armadas Rebeldes, Guatemala's first post-1954 insurgency [14]. While the uprising was unsuccessful, for many, this marks the beginning of the thirty-six-year civil war because it was the first attempt of what would later become an armed guerilla movement [1].

For the next forty years, Guatemala experienced waves of violence between armed guerilla groups and counterinsurgency efforts inflicted by the government [1]. By the late 1970's, the military had subdued opposition groups and almost obliterated the guerilla movement, resulting in their consolidation of full power [1]. After gaining full control, the military turned its efforts on eradicating entire communities of indigenous Mayan's in order to destroy all guerrilla bases [1]. While the military justified their actions as a necessary measure, aimed at state terrorists, the result was later considered an act of genocide directed at indigenous Mayan communities [1].

\subsection{The Story of "Parque de la Paz"}

Until the late 1970's, Santiago Atitlán was relatively unaffected by the violence of the civil war [15]. In 1980, however, the military had moved into Santiago Atitlán, building a military base in an effort, according to the military, to protect Santiago citizens from anti-communist guerilla groups that had taken refuge in the surrounding mountain areas. Their method of protection, however, was to match counterinsurgency by the guerillas with violence against the citizens of the community [16]. This included scorched earth campaigns and an imposed village patrol system known as the Patrullas de Autodefensa Civil (PAC), or Civil Defense 
Patrols. Though Governmental Decree 222-83 on April 14, 1983 officially created PAC's, the patrols had been functioning, or organized, around Guatemala since 1981 [17]. The PAC forced civilians to participate in military actions, which meant that civilians were required to engage in military operations and become exposed to military combat [17]. The PAC's effectively demolished the authority of the indigenous Mayan systems, and became a method of exercising complete control over Mayan communities [17]. The existing authority structures were destroyed, and replaced with military authorities. The local economy was disrupted because workers were afraid to go out early or stay late in their fields. It was not uncommon for workers to be kidnapped or killed under suspicion of aiding guerillas if they carried food for their lunches or machetes' an essential farming tool.

While the military occupied Santiago Atitlán, the community suffered frequent killings, disappearances, and instances of violence and rape [18]. After almost a decade of military occupation in Santiago, guerilla actions had nearly ceased, however, the army only continued to increase violent counterinsurgency tactics [16]. Blaming this violence on "terrorist activities", the military was able to legitimize its continued occupation of Santiago [16]. Social stability collapsed as the community succumbed to growing fear and suspicion because it had become unclear who was responsible for the constant violence, and why the violence continued.

Eventually, the level of terror in the town had led to desperation and intolerance that erupted in the early morning hours December 2, 1990 [16, 18]. On the night of December 1, a military commander and four soldiers had been drinking, and left a cantina in search of a particular woman that the commander was attracted to. After the men began pounding on her door, her terrified family called for help. A group of neighbors, tired of the behavior of the military officials, came over in an attempt to seize the soldiers and drag them to jail. In the ensuing scuffle, the commander shot his gun into the air. A patrol of military soldiers had gone to investigate the source of the gunshot, and found the group of neighbors trying to drag the drunken soldiers to the jailhouse. The patrolling soldiers that had come to investigate intervened, and in the process shot and paralyzed a young boy from the waist down. Instead of returning home, the group of neighbors went to the Catholic Church and rang the church bells to wake the rest of the town up. The group that had crowded in the church square included the mayor, the mayor-elect, a few thousand men, women and children. The crowd decided to walk to the military base in order to peacefully meet with the soldiers and demand justice for the commander. They carried white flags in order to show their peaceful intentions. The soldiers ignored the flags and fired their guns into the crowd, killing 13 and wounding about 35 Atitecos. The thirteen that were killed were left where they died, as a testament to the violence incurred by the military. The following day, 15,000 community members contributed their signatures and thumbprints to a letter demanding that the government punish the soldiers and remove military presence from Santiago. In an unprecedented move, then President Venicio Cerazo Arevalo demanded that the military leave Santiago on December 20, 1990. The citizens of Santiago had been the first community to successfully rid their town of occupiers, in the entire history of Guatemala. According to Mr. Rafael Estrada Arteaga, Coordinador de la oficina de seguridad (Coordinator for the Office of Security), Santiago became an "example for all of Guatemala" (July 2012).

\section{Significance}

The massacre at Santiago Atitlán is significant not only because it was the first community to oust its military inhabitants and remain free of their presence, but the event was unprecedented in both local and international political impact [19]. According to Carlson [19], the aftermath of the massacre was unprecedented because it was immediately publicized. Reporters and human rights groups that were investigating the shootings were, as journalist Victor Perera wrote, "met by an outpouring of denouncing from the Atitecos, as if a floodgate of emotions had been opened following a decade of deathly silence" [20]. The night after the massacre, the mayor and mayor-elect had access to uncensored national television where they described the town's entire history of violence inflicted by the army [19, Interview 2012]. Less than 24 hours after the tragedy, a petition that contained 15,000 signatures and thumbprints had been produced, demanding a trial and punishment for those responsible for the killings.

In response to the publicity of Santiago's massacre, the United States decided to restrict all military aid to Guatemala, and the European Economic Community condemned the country. Alongside international criticism, the Guatemalan Catholic Archdiocese issued a report that revealed the Army's culpability in crimes of genocide, and recommended serious changes in military policies [19]. Faced with such international and national attention, the Guatemalan Army vacated Santiago Atitlán.

Prior to the military occupation, Santiago was a factionalized community. It became further fractionalized with the military's presence during the 1980's. This episode of violence was significant because the entire community was able to overcome the fraction and come together to form a collective action movement within their town. The fear and silence that the community had lived within was temporarily suspended as the town came together to confront the military. Social divisions were overcome through the unity against a common enemy.

\section{Current Community Perceptions and Uses of Park}




\subsection{Parque de la Paz” Physical Description}

The "Parque de la Paz" was built by the Catholic Church, in memory of the 13 people who perished fighting for Santiago, Atitlán. The park is constructed in the city Panabaj, Santiago Atitlán, Sololá half a kilometer from the village of Santiago Atitlán (interview June 2012). It is constructed of stone that was taken from the dismantled garrison. It is built as a terrace where there are markers for each person who died, in the spot where they fell. In addition, there is an open air alter towards the back, along with a presider's chair, and lectern. The park is set up like a Catholic Sanctuary, so that a mass could take place on the 2 nd of each month. The park is built alongside what looks to be a plot of land, however, according to a community legend, it was perhaps the site of a mass clandestine grave. A well sits near the street, or front, of the park which represents a well that had existed there before, according to some informants, where people were thrown in and tortured.

\subsection{Data Collection}

Forty-one interviews were included in my field research. To gather my information, I would ask informants open-ended, general questions about the park. Such as, "can you tell me what you know about the history of Santiago Atitlán?" If I was talking to someone who was here when the events of December 1 occurred, I asked "If they could tell me what it was like during that time?" If the interviewee was not in the area during the time of the massacre, I asked how people learned about this history. Lastly, I want to know why people think that the subject is rarely talked about around Santiago. I will present one interview as an example, and present themes of interviews in the conclusion.

This interview I had with a young Atitecan is representative of conversations with most informants during my stay in Santiago. This young informant took me on a tour of sorts, to some of the significant places in the city. As we walked to the front of the park, he began telling me the story about the massacre. When I asked if the teachers taught about the history of the park, he explained that teachers don't teach kids now in school about the history of Parque de la Paz. I wanted to know why, and he shrugged his shoulders and said "I think it's because of the president now. Do you know about the president now?" (At this time, the President was Otto Fernando Pérez Molina, During the 1990s, before entering politics, he served as Director of Military Intelligence, Presidential Chief of Staff under President Ramiro de León Carpio, and as chief representative of the military for the Guatemalan Peace Accords). I said yes, wasn't the current president a part of the military regime that ruled during the massacres? He nods. He went on to explain that people just want to forget about the past. The attitude is more like, "It's in the past, why think about it, and let's move on." I tried to ask why it isn't taught or talked about in an effort to prevent atrocities in the future. Basically, my informant explained, the answer is just far too complicated.
Crossing the street, we entered the park and sat down on the wall. To elaborate on how the park commemorates more people than there are headstones, he pointed to the area above us, north into the mountainside. He said 25 guerillas were massacred there. The park is a memorial for them, which is indicated in the short history blurb on the entrance sign according to my informant.

We began to discuss, again, about the fact that kids are not taught in school about this history. Again, he said he thought that it might be because of the current president. It was difficult to ask the questions I wanted to ask, because while his English was very good, I think the concepts didn't translate easily. I tried to ask about the Pan-Mayan movement and the push for cultural revitalization and preservation. I tried to explain that with cultural revitalization/preservation, the history of the Mayan people is important because they have a direct impact on Mayan life and traditions. I said I didn't understand how there is such a fervor with some Mayan organizations to promote Mayan culture and identity, when Mayan identity is directly impacted by Guatemala's history, especially in Santiago where a small community managed to accomplish a pretty impressive act. Again, he shrugged his shoulders and agreed that he didn't understand either.

He pointed at the church that was located on the north end of the park. He told me that the church was the original church that had been established there before the instances of violence. He said that the priest that resided over the church did a lot to broker peace, or develop dialogue, between the guerilla and the army.

I mentioned some of the girls I had met from a social work program working in Santiago had told me that the well in the park symbolized the holes that were dug, where people were tied up and thrown into the water. I asked if this was what the well in the park had symbolized. He said that the well was supposed to symbolize all the different types of holes like this in other places. I asked why, if people want to forget, move on, and not talk about the civil war, why Atitecos' would build a symbol that was so blatant about the gory details of the war. Why would they make a structure that existed for all to see, if really people don't want to talk about it? Again, a shrug of the shoulders.

I asked him about a story I read in my research about the building or establishment of the park. I had read that when the park was being built, a mass grave was discovered. The military ordered the cessation of the park's establishment, or else they would revoke their agreement and come back to Santiago. ST1 said that wasn't true.

In reference to the creation of the park, my informant explained that is still there because it is considered to be a tourist attraction and a way to make some monetary income. Tuc Tuc drivers will offer to take tourists there and be a little tour guide for a price.

This interview mirrored most other interviews in that perceptions are based on person to person folktales rather than formal education and written events. 


\subsection{Observation Notes}

I reserved two hour blocks of time at different times of the day in observation of park traffic. In total, 40 hours of time were spent in observation. During 20 of those hours, I recorded the number of people that had come to the park, and categorized those visitors into gender groups, age groups, activity in the park, and transportation to and/or from the park. Approximately 500 individuals were seen in or at the perimeter of the park during that time (About 150 individuals per 4 hour increments). Based on my time spent in observation, the park seems to be a point of transition between roads, and a main stop to grab a pick-up or tuc tuc along highway 14, which travels around the lake. The people that waited were mostly women, almost all wearing their traditional traje garb, and their young children. If any males were waiting, I noticed they would wait further back behind the women instead of with them, or sit in a different location. The people I saw walking on the road between Santiago and Panabaj were mainly men, or young men, with the majority heading towards Santiago. The majority of older men wore traditional clothing, and all were holding tools of their trade. Most carried bundles on their backs as a means of transport. Some men had bundles of wood, some had bundles of leaves/grasses, and some had a makeshift "backpack." For example, I saw one man that had strapped a plastic egg-crate basket on his back to use in order to carry things.

I never saw anyone socializing within the park. Socializing occurred around the perimeter of the park instead. Because there was no socializing or "hanging out" of any kind, it seemed as though the park is an area that is used for local individuals to get between Panabaj and Santiago, or as a shortcut to get to the road north of the main road. Those who lingered within the park were tourists, but even then, tourists didn't really hang around for long.

Throughout the time I spend observing in the park, I was able to interact with both tourists and Atitecos that were at the park. Some tourists related similar experiences of my own when asking questions about the park and its location. For example, one of the older European tourists stopped and talked to me, interested in what I was doing. She made a comment that it seemed like no one knew about the park when they were asking for directions. I wondered if this is more evidence that most people don't know about the park, or just a coincidence that no one understood us?

\section{Marginalization of Importance}

The marginalization of importance given to the Peace Park can most likely be explained by Santiago's history of social division. Before the Peace Park was built, and the military was ousted from the town, the social tensions that had been exacerbated by military occupation resurfaced. Common crime and a resurgence of factionalism, particularly religious, emerged only a few years after the military left Santiago. In 1993, the Guatemalan journalist and scholar, Victor Perera commented, "Santiago remains one of the most embattled communities in the Guatemalan highlands, riven with political and religious feuds that pit family against family, ladino against natural, and Catholic against Protestant" [20]

According to Carlsen [19], religious fractionalization is particularly vicious, as religion has been a source of answers to the town's social woes. As an example, Carlsen [19] explains, that Santiago Atitlan's Protestant churches and missions usually refer to the evilness of its traditional past, and to those Atitecos that continue to perform ancient rituals. Through one of my informants, Carlsen's [19] analysis was confirmed. During a walk through Santiago's Catholic Cathedral, my informant was explaining various aspects of the church and its history. My field notes from that day read:

"At one point, he pointed at a statue of the Virgin Mary that was sitting in the center of the grassy area, next to a tree. The head of this statue was missing. He said that it was chopped off by a group of evangelicals. The biggest problem in Santiago now, he included, is the rivalry between these two church factions. At this point, I took the opportunity to ask about some of the things I have read in my research materials regarding the feud between the Catholics and evangelicals, I asked if it was still true if the evangelicals blasted music and sermons over the town, from a radio station. He nodded, I asked if Santiago still had the tradition of Semana Santa, when the effigy of Maximon is carried through the streets of Santiago on the shoulders of his telinel (or shawman). Again he told me this was correct. We left this courtyard, turned right on the front veranda of the church, and walked toward the main entrance. Nodding towards our right, he indicated a blue painted, small room, at the end of the row of the structure. It was painted blue, and had a dome on top. It was a part of the rest of the building, but it looked like it was separate. My informant explained that this used to be Maximon's house, a Mayan deity of the "old ways" believed to have control of both nature and society. Ritual worship was necessary to keep the community in harmony and nature. He used to be kept inside, where people could go and worship. Because of Mayan and Catholic 'synchronicity', Maximon has taken on the meaning that is similar to Jesus Christ. Now, however, Maximon does not reside in the blue building, but in a mansion nearby."

\section{How Does the Peace Park fit in within the Transitional Justice Paradigm?}

Based on the evidence I collected from various members of Santiago, Atitlán society, the history of the peace park is being submerged beneath the larger, national process of transitional justice occurring in Guatemala. While I expected to find Atitecos that were forthcoming and willing to share the history of their town, I found a community that was still quiet about their past. While the older members of the community I interviewed thought it was extremely important to teach the past to future generations, the younger members of society knew the story but weren't interested in its 
significance, or visiting the park on the 2nd of each December. The park, to these younger informants was "boring" and a way for tuc tuc drivers to earn more money by being an informal tour guides.

These results fall in line with Barsalou and Baxter's [8] evaluation of memorials and their connectedness with other transitional justice mechanisms. In the authors' [8] analysis, memorialization efforts need to be connected to other transitional justice mechanisms, like truth telling initiatives, judicial process and educational reform, in order to have a broader impact on social reconstruction. Because the incident in Santiago took place before peace keeping negotiations started, it is not connected to the larger transitional efforts ongoing in the country. Furthermore, transitional justice mechanisms have yet to be fully implemented in Guatemala.

The first transitional justice mechanism initiated in Guatemala was the formation of the Guatemalan Historical Clarification Commission (Comisión para el Esclarecimiento Histórico, or $\mathrm{CEH}$ ). This was the first international truth commission that the United Nations established as a part of the Oslo Accords peace process in 1994 [17]. The final report of the $\mathrm{CEH}$, presented on February 25, 1999, declared that the state of Guatemala had committed acts of genocide against the Mayan people, under the framework of counterinsurgency [17]. Three weeks after the report was made public, the government publicly repudiated the Commission's findings and recommendations, including the creation of a governmental office that would provide any follow-up to the Commission's report [21].

The CEH was a part of the Oslo Accords signed in 1994, however, they could not start their investigations until after the signing of the final peace accords in 1996. Because the work of the truth commission was halted, and many viewed the $\mathrm{CEH}$ as incapable of dealing with the scope of violations in Guatemala, the Catholic Church established the Recovery of Historical Memory (REMHI) Project. The REMHI project was a private truth commission that worked outside the official peace process and was able to circumvent the political limitations of the CEH [22]. The church was able to collect more testimonies in more regions of Guatemala. Beginning its work in 1995, the REMHI worked for over two years before completing its final report. On April 24, 1998, Bishop Juan Gerardi, the head of the REMHI issued the final report, a four-volume report, entitled "Nunca Mas (Never Again)" [22]. Unlike the forthcoming $\mathrm{CEH}$ report, the REMHI report listed the names of government and military officials that were responsible for carrying out crimes [22]. The report also included recommendations for reforms that would promote reconciliation. Three days after the report was made public, Bishop Juan Gerardi was assassinated by members of the Presidential General Staff [22]. This served as a powerful example of how the political elite were determined to keep the past hidden and prevent reform [22].

The peace accords were supposed to improve the educational system, and mandated curriculum reform that would address issues of diversity, and the history of the civil war. The findings of the truth commissions were supposed to be included in the new standards set for textbooks, in order to teach the historical and structural causes of the war. However, these changes haven't become reality. According to Oglesby [21], Guatemala still remains a country that has the lowest ratio of state spending on education than any other country in Latin America. Furthermore, state reform has only altered standards for primary school where new standards were set to deal with the issue of multiculturalism [21]. The mandates were supposed to correct those traditional depictions of indigenous cultures as if they were relics of history. Instead, history was removed from the curriculum and replaced with "social studies" [21].

While two truth commissions have investigated and charged the Guatemalan government with acts of genocide, justice has not been brought to the perpetrators at the highest level. Indeed, during his brief time in power, General José Efraín Ríos led a government campaign to eradicate Mayan villagers, and in the spring of 2013, Guatemala brought charges of genocide and crimes against humanity against him. One month after being found guilty, his conviction was overturned on procedural grounds [23]. This was the first country to convict and charge a former leader of genocide crimes, even if the charge was dismissed. Nearly thirty years after his removal from office, corruption abounds and justice is impeded by those aiming to conceal the past.

\section{Conclusions}

The Peace Park is a forgotten bit of real estate on the outskirts of Santiago. The park is representative of TJ mechanisms as an example of memorialization. Most memorials are erected by the victor after a period of unrest during national events. The Peace Park was established one year after a single community event. Memorials tend to be shocking in their scope i.e the genocide memorials in Rwanda, yet the Peace Park is much understated. TJ requires that education be provided so that "we never forget". There is no education in Guatemala that explains the events of December 2, 1990. Rather, the events are spoken from generation to generation. This has resulted in folklore and inaccurate historical accounts, especially because community residents continue to remain silent about the past out of fear of possible retribution. The importance of the events has been marginalized as a result of the long history of social division within the community and within the country as a whole. The Park has been reduced to a shortcut from one point to another, and a place for tuc tucs to pick up patrons.

20 percent of interviewees were equal to or greater than 40 years of age, and $80 \%$ were 39 years or less.

Themes that emerged from my interviews are summarized as:

Thirty percent of those interviewed were disinterested in the park.

Forty percent of those interviewed have not received formal education about the park. 
Fifty percent of those interviewed would rather move on and not think about the events associated with the park.

Twenty percent of those interviewed that knew the story of the Peace Park, did not elaborate on their own feelings or connection to the park, if any. My interpretation, based on the visible body language of these participants, was that they were not comfortable talking about the park or the civil war.

The marginalization of importance given to the Peace Park, can most likely be explained by Santiago's history of social division. In 1993, the Guatemalan journalist and scholar, Victor Perera commented, "Santiago remains one of the most embattled communities in the Guatemalan highlands, riven with political and religious feuds that pit family against family, ladino against natural, and Catholic against Protestant" [20]. Until the TJ recommendations are implemented in the country, and real social reconciliation can occur, Santiago seems destined to remain as Perera described it.

\section{REFERENCES}

[1] Afflitto, Frank M. and Paul Jesilow. The Quiet Revolutionaries: Seeking Justice in Guatemala, University of Texas Press, Austin 2007.

[2] Hamber, Brandon, Liz Sevcenko and Ereshnee Naidu. Utopian Dreams or Practical Possibilities? The Challenges of Evaluating the Impact of Memorialization in Societies in Transition, The International Journal of Transitional Justice, Vol. 4, No. 3, 397-420, 2010

[3] Hatto, Ronald. From Peacekeeping to Peacebuilding: The Evolution of the Role of the United Nations in Peace Operations, International Review of the Red Cross, Multinational Operations and the Law, No. 95, 495-515, 2013

[4] Hinton, Alexander Laban. Transitional Justice: Global Mechanisms and Local Realities after Genocide and Mass Violence, Rutgers University Press, New Jersey, 2011

[5] Andrieu, Kora. Transitional Justice: A New Discipline in Human Rights, Online Encyclopedia of Mass Violence [online], published on 18 January 2010, Online Available: http://www.massviolence.org/Transitional-Justice-A-New-D iscipline-in-Human-Rights, ISSN 1961-9898

[6] United Nations. Guidance Note of the Secretary-General: United Nations Approach to Transitional Justice, United Nations, New York, 2010

[7] Ishay, Micheline R. The History of Human Rights: From Ancient Times to the Globalization Era. Los Angeles: University of California Press, 2008

[8] Barsalou, Judy and Victoria Baxter. The Urge to Remember: The Role of Memorials in Social Reconstruction and
Transitional Justice, Stabilization and Reconstruction Series No. 5, United States Institute of Peace, Washington D.C., 2007

[9] Roman, David. Transitional Justice? Criteria for Conformity of Lustration to the Right to Political Expression, Europe-Asia, Vol. 56, No. 6, 789-812, 2004

[10] Zounmenou, David and Naomi Kok. Between War and Peace in the Eastern DR Congo, New Routes: A Journal of Peace Research and Action, Vol. 17, No.4, 2012

[11] Stone

[12] Burnet, Jennie E. Who's Genocide? Whose Truth? Representations of Victim and Perpetrator in Rwanda, Alexander Labon Hinton and Kevin Lewis O’Neil, eds. Duke University Press, Durham, 2009

[13] Grandin, Greg, Deborah T. Levenson, Elizabeth Oglesby, eds. Ten Years of Spring and Beyond, The Guatemalan Reader: History, Culture, Politics, Duke University Press, Durham 2011

[14] Grandin, Greg, Deborah T. Levenson, Elizabeth Oglesby, eds. We Are Officers of the Guatemalan Army: November 13 Rebel Movement, The Guatemala Reader: History, Culture, Politics, Durham: Duke University Press, 2011

[15] Stewart, Julie. The Paradox of Political Opportunity: The Problems and Promise of Community Mobilization in Post-Conflict Guatemala, 2000

[16] Carlsen, Robert S. Social Organization and Disorganization in Santiago, Atitlán, Ethnology, 141-160, 1996

[17] Commission for Historical Clarification. Guatemala Memory of Silence: Report of the Commission for Historical Clarification Conclusions and Recommendations, 1999

[18] Wilson, Richard. The Politics of Remembering and Forgetting in Guatemala, Guatemala After the Peace Accords, University of London Institute of Latin America Studies, London, 1998

[19] Carlsen, Robert S. The War for the Heart and Soul of a Highland Mayan Town, Revised Edition, University of Texas Press, Austin, 2011

[20] Perera, Victor. Unfinished Conquest: The Guatemalan Tragedy, University of Berkely Press, Berkely, 1993

[21] Oglesby, Elizabeth. Educating Citizens in Postwar Guatemala: Historical Memory, Genocide and the Culture of Peace, Radical History Review, no. 97, 2007

[22] Kauffman, Craig. Transitional Justice in Guatemala: Linking the Past and the Future, International Studies AssociationSouth Region Conference, Miami, 2005

[23] Laplante, Lisa J. Memory Battles: Guatemala's Public Debates and the Genocide Trial of José Efraín Ríos Montt, Boston Legal Studies Research Paper Series, Research Paper No. 15-02, 2014 